\title{
Analisa Penggunaan Sistem Informasi Akuntansi (SIA) Berbasis Komputer pada PT. Bank Perkreditan Rakyat Darul Imarah Jaya Aceh Besar
}

\author{
Saiful AMRI * \\ Fakultas Ekonomi, Universitas Serambi Mekkah, \\ Jalan Batoh, Lueng Bata, Kota Banda Aceh, Provinsi Aceh, Indonesia \\ saiful.amri@serambimekkah.ac.id
}

\section{Article's history:}

Received 18 February 2020; Received in revised form 20 July 2020; Accepted 26 August, 2020;

Published 30 August 2020. All rights reserved to the Lembaga Otonom Lembaga Informasi dan Riset Indonesia (KITA INFO dan RISET).

\section{Suggested citation:}

Amri., S. 2020. Analisa Penggunaan Sistem Informasi Akuntansi (SIA) Berbasis Komputer pada PT. Bank Perkreditan Rakyat Darul Imarah Jaya Aceh Besar. JEMSI (Jurnal Ekonomi, Manajemen, dan Akuntansi), Volume 6 (2): 90-100. DOI: https://doi.org/10.35870/jemsi.v6i1.342.

\section{ABSTRAK}

Penelitian ini bertujuan untuk mengetahui penerapan penggunaan sistem informasi akuntansi berbasis komputer pada PT. Bank Perkreditan Rakyat Darul Imarah Jaya yang merupakan lembaga yang bergerak pada bidang Perbankan. Analisis dalam penelitian ini dengan menggunakan metode deskriptif, yaitu membandingkan teori dengan data yang didapat di lapangan dengan pendekatan studi kasus dan dianalisis secara kualitatif. penelitian ini dilakukan pada PT. Bank Perkreditan Rakyat Darul Imarah Jaya. Penulis langsung mendapatkan informasi dari PT. Bank Perkreditan Rakyat Darul Imarah Jaya melalui wawancara, yaitu dengan mengadakan Tanya jawab langsung dengan pejabat dan karyawan yang terkait dengan permasalahannya yang akan dibahas. hasil penelitian menunjukkan bahwa PT. Bank Perkreditan Rakyat Darul Imarah Jaya telah menggunakan sistem pengolahan data elektronik (electronic data processing system) terhadap sistem informasi akuntansi (SIA). Selain adanya tanggung jawab dalam pengolahan data, PT. Bank Perkreditan Rakyat Darul Imarah Jaya juga menambah sub pengendalian intern dalam sistem pengolahan data berbasis komputer yang terdiri atas pengendalian umum dan pengendalian aplikasi. Secara umum sistem informasi akuntansi (SIA) berbasis komputer pada PT. Bank Perkreditan Rakyat Darul Imarah Jaya telah berjalan dengan baik sesuai dengan penggunaan SIA dan pengendalian yang dilakukan telah menghasilkan percepatan didalam pemrosesan transaksi juga mengurangi kesalahan dalam pekerjaan.

Kata Kunci: Sistem Informasi Akuntansi; Berbasis Komputer.

JEL Classification: L86; H83.

\section{PENDAHULUAN}

Perbankan memiliki peranan yang sangat strategis dalam menunjang berjalannya roda perekonomian dan pembangunan nasional mengingat fungsinya sebagai lembaga intermediasi, serta alat transmisi kebijakan moneter. Menurut Undang-Undang RI Nomor 10 Tahun 1998 tentang Perbankan, yang dimaksud dengan bank adalah badan usaha yang menghimpun dana dari masyarakat dalam bentuk kredit dan atau bentuk-bentuk lainnya dalam rangka meningkatkan taraf hidup rakyat banyak.

Dalam Undang-Undang No.10 Tahun 1998 tentang Perbankan, menurut jenisnya bank terdiri dari Bank Umum dan Bank Perkreditan Rakyat (BPR). Bank Perkreditan Rakyat (BPR) adalah bank yang melaksanakan kegiatan usaha secara konvensional atau berdasarkan prinsip syariah yang dalam kegiatannya tidak memberikan jasa dalam hal pembayaran (Peraturan Bank Indonesia No. 6/22/PBI/2004). BPR sebagai lembaga perantara keuangan (financial intermediary) yang menghimpun dana dari masyarakat dan menyalurkan kembali kepada masyarakat dalam bentuk kredit, BPR juga harus menjaga kepercayaan yang diberikan masyarakat dalam mengelola dana mereka. Perwujudan dari kesungguhan BPR dalam mengelola dana masyarakat adalah dengan menjaga kesehatan kinerjanya karena kesehatan kinerja sangat penting bagi suatu lembaga usaha. Dengan mengetahui tingkat kesehatan usaha, para stakeholders dapat dengan mudah menilai kinerja lembaga tersebut. 
Kondisi financial dan perkembangan perusahaan yang sehat akan mencerminkan efesiensi dalam kinerja yang baik dalam perusahaan dan faktor produksi modal mempunyai arti yang penting (Susilo, 2000:30).

PT. Bank Perkreditan Rakyat Darul Imarah Jaya mengunakan sitem informasi akuntansi berbasis komputer yang menunjang proses akuntanbilitas, merupakan salah satu organisasi usaha yang bergerak pada bidang perbankan serta berperan dalam proses pemerataan pembangunan ekonomi dalam usaha meningkatkan taraf perekonomian pengusaha kecil khususnya yang berada di desa-desa. Adapun aktifits-aktifitas yang dilakukan oleh PT. Bank Perkreditan Rakyat Darul Imarah Jaya terdiri dari usaha-usaha menghimpun dana dari masyarakat dalam bentuk tabungan dan deposito berjangka serta menyalurkan dana kepada masyarakat dalam bentuk pemberian kredit kepada pengusaha kecil di desa-desa. Dengan beragamnya transaksi operasional kerja perusahaan, maka beragam pula sistem informasi akuntansi berbasis komputer dalam melakukan proses pengolahan transaksitransaksi menjadi informasi-informasi dan laporan keuangan. Hal ini bermanfaat untuk mengontrol secara jelas seluruh aspek-aspek keuangan yang merupakan kegiatan rutin pada PT. Bank Pekreditan Rakyat Darul Imarah Jaya.

Berbeda halnya dengan Bank Indonesia atau Bank Umum. Bank Perkreditan Rakyat adalah bank yang memiliki ruang lingkup lebih kecil. Disamping dibatasi oleh pembatasan usaha bersifat operasional yaitu Batas Maksimum Pemberian Kredit (BMPK) yang diatur dalam surat Keputusan Direksi Bank Indonesia No.26/21/KEP/DIR tanggal 29 Mai 1993. Bank Perkreditan Rakyat juga dibatasi dalam melakukan beberapa kegiatan seperti giro, transfer dan valuta asing.

Perkembangan badan usaha sekarang ini tidak terlepas dari adanya penyajian informasi keuangan yang merupakan ikhtisar penting dan fundamental dari aktivitas perusahan dengan menggunakan teknologi agar mampu menciptakan efisien dan efektifitas dalam menyajikan berbagai informasi yang dibutuhkan, sehingga dalam menjalankan aktifitas bisnis dapat mencapai tujuan. Untuk terciptanya laporan keuangan sesuai dengan harapan pihak-pihak intern maupun ekstern perusahaan maka dibutuhkan suatu sistem informasi akuntansi berbasis komputer yang jelas dan kongkret dalam mengolah seluruh teransaksi menjadi informasi-informasi yang dibutuhkan.

Untuk menciptakan informasi akuntansi sesuai dengan harapan para pemakai, James Hall (2001: 18) mengungkapkan 3 (tiga) hal mendasar mengapa sistem informasi akuntansi begitu penting untuk mendukung fungsi kepengurusan (stewardship), untuk mendukung pengambilan keputusan manajemen, untuk mendukung kegiatan operasi perusahaan hari demi hari. Kuncinya jika perusahaan tidak memiliki sitem informasi akuntansi berbasis komputer yang baik, perus8ahaan tidak dapat berharap untuk menyediakan informasi yang baik, dalam hal ini yang menunjang proses pelaksanaan akuntanbilitas.

Pelaksanaan akuntabilitas memang diterapkan di setiap perusahaan begitu juga dalam dunia perbankan. Dengan adanya perkembangan globalisasi diantaranya jumlah bank yang semakin banyak, perluasan jaringan-jaringan kantor, peningkatan volume usaha serta jenis maupun mutu produk menuntut adanya perbaikan-perbaikan serta perubahan-perubahan diantaranya pengunaan sistem informasi akuntansi handal yang menunjang pelaksanaan akuntanbilitas.

\section{TINJAUAN KEPUSTAKAAN}

\section{Sistem Informasi Akuntansi}

Bodnar dan Hopwood (2000:1), suatu sistem dapat didefinisikan sebagai kumpulan sumber daya yang berhubungan untuk mencapai tujuan tertentu.Definisi sistem menurut Romney (2003:2), adalah "a system is asset of two or more interrelated components that interact to achieve a goal". Pengertian menurut Mulyadi (2001:23), sistem pada dasarnya merupakan sekelompok unsur yang erat dan berhubungan satu dengan yang lainnya, yang berfungsi bersama-sama untuk mencapai tujuan tertentu. Sedangkan pengertian sistem menurut Winarno (2006:33) adalah sekumpulan komponen yang saling bekerja sama untuk mencapai tujuan tertentu hampir sama dengan pengertian sistem menurt Romney (2003:41), masing-masing komponen tersebut memiliki fungsi yang berbeda-beda, antara lain:

a. Input berfungsi untuk menerima masukan dari luar sistem.

b. Proses berfungsi untuk mengubah input menjadi output.

c. Output berfungsi untuk mengirimkan hasil olahan kepada pihak di luar sistem.

d. Kontrol berfungsi untuk mengendalikan komponen lain agar berfungsi seperti yang diharapkan.

e. Batas sistem berfungsi untuk memisahkan sistem dengan lingkungannya atau

f. dengan sistem lainnya. 
Sedangkan menurut Winarno (2006:35) mengidentifikasikan informasi segala data yang sudah diolah sehingga berguna untuk pembuatan keputusan. Lebih lanjut Winarno (2006:57) mengemukakan karakteristik informasi yang baik, yaitu:

a. Akurat

Menggambarkan kondisi objek yang sesungguhnya

b. Tepat waktu

Informasi harus tersedia sebelum keputusan dibuat karena seringkali informasi tidak diperlukan lagi setelah keputusan dibuat.

c. Lengkap

Informasi harus mencakup semua yang diperlukan oleh pembuat keputusan. Lengkap tidak berarti memberikan semua informasi.

d. Relevan

Informasi harus berhubungan dengan keputusan yang akan diambil.

e. Terpercaya

Isi dari informasi tersebut harus dapat dipercaya (reliable).

f. Terverifikasi

Informasi harus dapat dilacak kesumber aslinya (verifiable).

g. Mudah dipahami

Informasi harus mudah dipahami oleh pembacanya.

h. Mudah diperoleh

Informasi yang sulit diperoleh bias tidak digunakan

Dalam Statemen Of Financial Accounting Concepts (SFAC) No. 2, Financial Accounting Standard Board yang dikutip oleh Romney dan Steinbart (2003:12) secara sederhana mendefinisikan akuntansi sebagai sistem informasi. Di dalam Standar Akuntansi Keuangan tersebut juga disebutkan bahwa tujuan utama akuntansi adalah untuk menyediakan informasi yang berguna bagi para pengambil keputusan. Bodnar dan Hopwood (2004:1) juga mendifinisikan akuntansi lebih mengarah pada suatu sistem informasi, yaitu: "Accounting as an information system, identifies, collect, process, and communication economic information about entity to a wide of people".

\section{Tujuan Sistem Informasi Akuntansi}

Sistem informasi merupakan suatu sistem yang memproses data menjadi informasi. Untuk mendapatkan informasi dibutuhkan data-data yang akan diproses yang nantinya informasi tersebut akan digunakan untuk acuan dalam mengambil keputusan. Dalam hal ini James A. Hall (2001:18) mengungkapkan 3 tujuan utama sistem informasi akuntansi yaitu:

1. Untuk mendukung fungsi kepengurusan (stewardship)

2. Untuk mendukung pengambilan keputusan managemen

3. Untuk mendukung kegiatan operasi perusahaan hari demi hari.

Menurut Kosasih (2001:5) tujuan sistem informasi akuntansi yaitu: "Untuk memenuhi kebutuhan para pemakai pemakai baik pihak ekstern maupun intern perusahaan yang masing-masing ini berbeda dengan kepentingannya, kalau pihak ekstern berorientasi pada neraca dan perhitungan laba rugi, sedangkan pihak intern berorientasi pada laba semaksimal mungkin. Prinsip ini berlaku untuk sistem informasi manual atau dengan menggunakan komputer". Sementara itu sistem informasi akuntansi menurut Henry (2002:7) adalah:

1. Mengalokasikan sumber daya langka masyarakat

2. Mengelola dan mengarahkan sumber daya di dalam perusahaan

3. Melaporkan pertanggung jawaban yang dikendalikan oleh individu sumber daya maupun organisasi.

Dengan demikian dapat diketahui bahwa sistem informasi akuntansu adalah sekumpulan dari unsur-unsur seperti peralatan dan manusia yang dirancang untuk mengubah dari data keuangan menjadi suatu informasi, dan kemudian informasi tersebut disajikan atau disampaikan kepada yang berkepentingan untuk pengambilan suatu keputusan. Sedangkan menurut Mulyadi (2001) tujuan dari penyusunan sistem informasi akuntansi adalah sebagai berikut: 
a. Untuk menyediakan informasi bagi pengelola usaha baru. Kegiatan pengembangan sistem informasi akuntansi terjadi jika perusahaan baru didirikan atau suatu perusahaan menciptakan usaha baru yang berbeda dengan usaha yang dijalankan selama ini.

b. Untuk meningkatkan kualitas informasi yang dihasilkan sistem yang sudah ada. Perkembangan usaha perusahaan menurut sistem akuntansi untuk menghasilkan laporan dengan mutu informasi yang lebih baik dan tepat penyajiannya, dengan struktur informasi yang sesuai dengan tuntutan kebutuhan manajemen.

c. Memperbaiki pengendalian dan pengecekan intern. Akuntansi merupakan alat pertanggungjawaban kekayaan suatu organisasi. Pengembangan sistem informasi akuntansi seringkali ditujukan untuk memperbaiki perlindungan terhadap kekayaan organisasi sehingga pertanggungjawaban terhadap pengguna kekayaan organisasi dapat dilaksanakan dengan baik. Pengembangan sistem informasi akuntansi bertujuan untuk memperbaiki pengecekan intern agar informasi yang dihasilkan dapat dipercaya.

d. Untuk menekan biaya klerikal dalam penyelenggaraan catatan akuntansi. Pengembangan sistem informasi akuntansi sering digunakan untuk menghemat biaya informasi yang merupakan barang ekonomi, sehingga untuk memperolehnya diperlukan pengorbanan sumber ekonomi lainnya.

\section{Fungsi Sistem Informasi Akuntansi}

Menurut Al Bahra (2003: 50 ) terdepat sembilan dimensi fungsi sistem informasi akuntansi yaitu;

1. Meningkatkan aksesibilitas data yang tersaji secara tepat waktu dan akurat bagi para pemakai, tanpa mengharuskan adanya perantara sistem informasi.

2. Menjamin tersedianya kualitas dan keterampilan dalam memanfaatkan sistem informasi.

3. Mengembangkan proses perencanaan yang efektif.

4. Mengidentifikasi kebutuhan-kebutuhan akan keterampilan pendukung sistem informasi.

5. Menetapkan investasi yang akan di arahkan pada sistem informasi.

6. Mengantifikasi dan memahami konsekuensi - konsekuensi ekonomi dari sistem informasi dan teknologi baru.

7. Memperbaiki produktifitas dalam aplikasi pengembangan dan pemeliharaan sistem.

8. Organisasi menggunakan sistem informasi untuk mengolah transaksi-transaksi, mengurangi biaya dan menghasilkan biaya pendapatan sebagai salah satu produk atau pelayanan mereka.

9. Perusahaan menggunakan sistem informasi untuk mempertahankan persediaana pada Tingkat paling rendah agar konsisten dengan jenis barang yang tersedia.

\section{Sistem Informasi Akuntansi Berbasis Komputer}

Seiring dengan pesatnya perkembangan teknologi informasi, bidang pengolahan data telah mendapat perhatian khusus pada hampir semua disiplin ilmu termasuk juga dalam lingkungan bisnis. Komputer sebagai unsur penting pengolahan data menjadi perangkat yang dominan digunakan dalam berbagai perusahaan jasa, dagang maupun industri. Kemampuan komputer dalam pemrosesan data yang akan dijadikan informasi akan lebih cepat dan akurat. Perbandingan kedua sistem pada gambar di bawah ini,

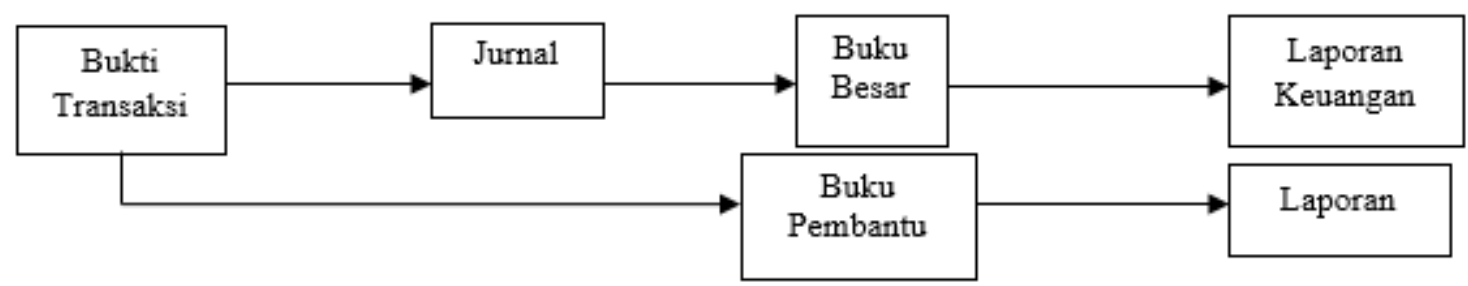

Gambar 1. Sistem Informasi Akuntansi Berbasis Komputer Sumber : Zaki Baridwan (2001:4)

Dalam SIA yang diproses secara manual (tanpa mesin) proses pengolahan data dilakukan dengan beberapa tahap tertentu. Siklus proses pengolahan data dimulai dengan bukti transaksi sebagai data input, dilanjutkan penjurnalan pada buku jurnal, pemindahan kebuku besar, kemudian penyiapan laporan keuangan. Dalam siklus ini dipersiapkan juga buku pembantu yang memperjelas perkiraan tertentu untuk menunjang penyusunan laporan. Namun jika pemrosesan data dengan menggunakan bantuan mesin komputer siklus pengolahan data dapat dipisahkan menjadi tiga, yaitu masukan (input), pengolahan (proses) dan keluaran (input). Input dalam pemrosesan dengan bantuan komputer ini adalah transaksi, yang kemudian direkam dalam file transaksi dan dilakukan penjunalan. Setelah dilakukan penjurnalan, data-data tersebut dipindahkan ke buku besar, 
kemudian baru dilakukan pembuatan laporan keuangan dan laporan lainnya. Sedangkan siklus pengolahan data akuntansi yang dilakukan dengan komputer dapat dilihat pada gambar berikut:

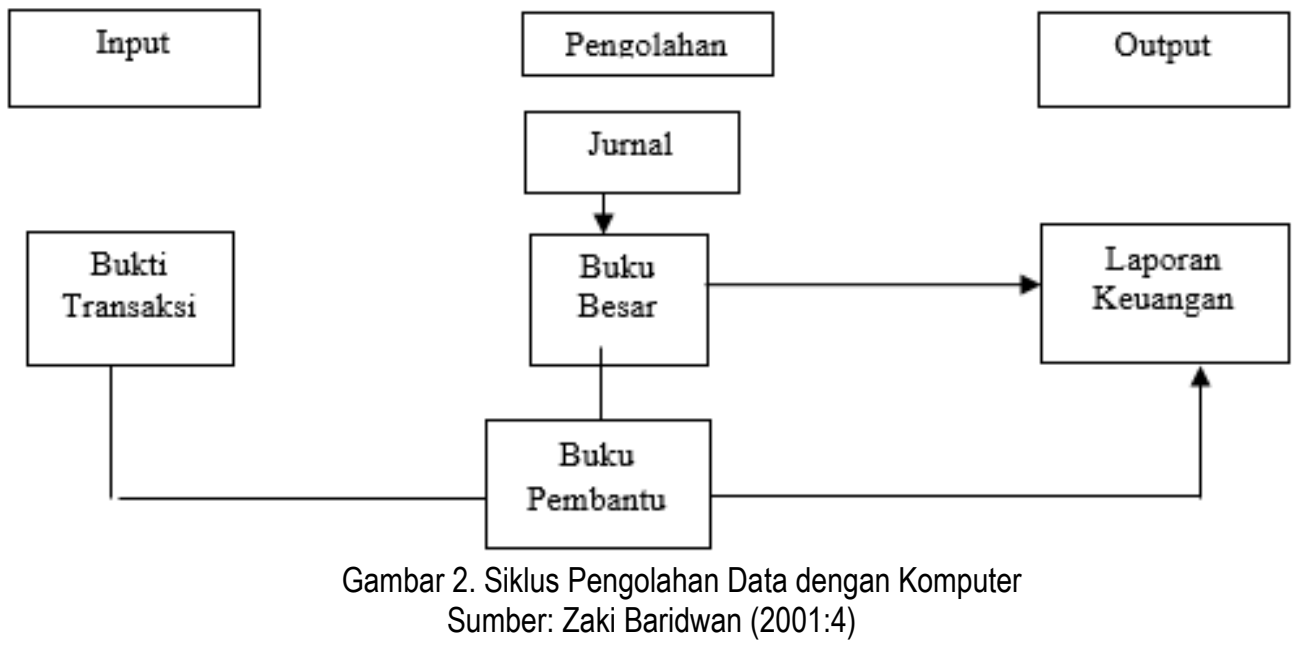

Menuurut Zaki Baridwan (2001:4) komputerisasi sitem akuntansi mempunyai keuntungan antara lain:

a. Biaya pengolahan informasi menjadi lebih hemat.

b. Kemampuan memproses dan menyimpan data dalam komputer atau media penyimpanan lain, lebih cepat dan lebih besar.

c. Kemampuan yang lebih besar untuk menciptakan berbagai mecam fungsi akuntansi termasuk penyiapan dokumen catatan akuntansi.

Akuntansi sebagai suatu sistem informasi harus dapat dipakai sebagai alat pengendali intern dan pengambilan keputusan untuk berbagai tujuan. Dalam hal ini sistem akuntansi dipakai untuk mengolah data yang dapat menghasilkan informasi yang berguna bagi para pemakai. Pengolahan data dilakukan dengan menggunakan alat-alat, prosedur-prosedur, formulir-formulir dan catatan-catatan. Siklus akuntansi yang dimulai dari bukti-bukti asli tentang transaksi yang dicatat dan seterusnya diolah. Selanjutnya sistem akuntansi memerlukan prosedur yang jelas dalam suatu transaksi untuk mencegah terjadinya pekejaan yang dilakukan diluar garis kebijaksanaan seperti penyelewengan dan penyalahgunaan wewenang, dimana sistem akuntansi yang disusun dengan baik, secara tidak lansung juga merupakan alat pengendalian yang mendukung keabsahan suatu transaksi, sehingga informasi atau laporan keuangan tersebut dapat dipercaya. Informasi merupakan output dari data yang telah diproses mempunyai manfaat bagi para pemakai untuk mengambil keputusan dari berbagai keperluan. Untuk mengubah data menjadi informasi dilakukan proses pengolahan data sebagai berikut.

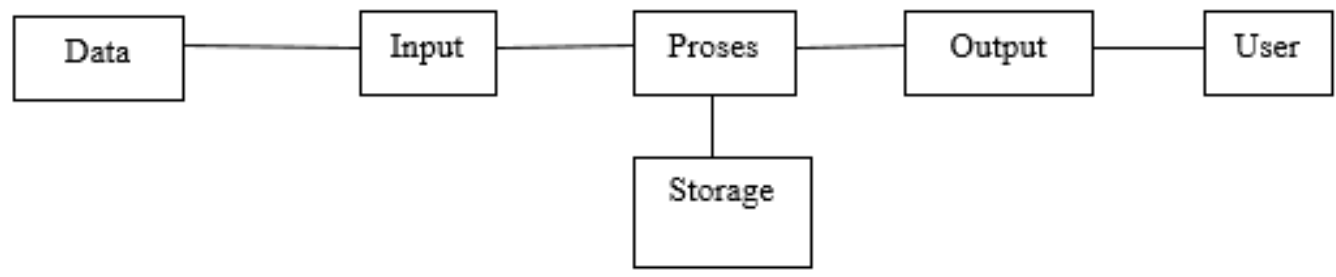

Gambar 3. Data Procesing Cycle

\section{Pengendalian dalam Pengolahan Data Berbasis Komputer}

Pengendalian dilaksanakan dengan cara-cara serta alat-alat sangat diperlukan sebagai sasaran untuk mengolah, memeriksa ketelitian dan kebenaran setiap data akuntansi dengan pengendalian akuntansi dan pengendalian administrasi. Pengendalian dalam suatu sistem pengolahan data berbasis komputer dibagi dua, yaitu Pengendalian Umum (General Kontrol) dan Pengendalian Aplikasi (Aplikasi Kontrol). Bahra al (2003:292), mendefinisikan pengendalian intern dalam sistem pengolahan data akuntansi berbasis komputer hampir seluruh bagian dapat diaplikasikan seperti pengolahan data penjualan atau penerimaan kas. 


\section{METODE PENELITIAN}

\section{Data dan Metode Pengumpulan Data}

sebagai berikut:

Pengumpulan data dilakuakan dengan metode dokuntasi, wawancara, dan studi kepustakaan yaitu

1. Dokumentasi

Moleong, (2009:217) menyebutkan pengumpulan data secara dokumentasi dilakukan dengan mempelajari, meneliti dan menelaah laporan keuangan BPR Darul Imarah Jaya yang menjadi sasaran dalam penelitian ini. Adapun data-data yang direncanakan akan digunakan berkaitan dengan proses pencatatan, pengelompokan, hingga pelaporan sistem informasi akuntansi berbasis komputer yang dikelola oleh BPR Darul Imarah Jaya.

\section{Wawancara}

Wawancara merupakan komunikasi langsung atau tidak langsung dalam bentuk interaksi tanya jawab dengan responden guna memperoleh data yang diperlukan. Wawancara adalah alat pengumpul informasi langsung untuk berbagai jenis data sosial baik yang terpendam maupun manifes (Moleong, 2009:186). Wawancara akan dilakukan kepada pihak-pihak yang berkaitan langsung dan bertanggung jawab dalam penyusunan laporan keuangan, yaitu staf akuntan BPR Darul Imarah Jaya.

3. Studi Kepustakaan

Data diperoleh dengan mempelejari literatur-literatur yang terkait dengan sistem informasi akuntansi berbasis komputer, dan bacaan-bacaan lain yang berkaitan dengan masalah yang diteliti guna mendapatkan landasan teori.

\section{Peralatan Analisis Data}

Marshall dan Kabalmay (2002:68), mengajukan teknik analisa data kualitatif untuk proses analisis data dalam penelitian ini. Dalam menganalisa penelitian kualitatif terdapat beberapa tahapan-tahapan yang perlu dilakukan diantaranya:

1. Mengorganisasikan Data

Peneliti mendapatkan data langsung dari subjek melalui wawancara mendalam (indepth inteviwer), dimana data tersebut direkam dengan tape recoeder dibantu alat tulis lainya. Kemudian dibuatkan transkipnya dengan mengubah hasil wawancara dari bentuk rekaman menjadi bentuk tertulis secara verbatim. Data yang telah didapat dibaca berulang-ulang agar penulis mengerti benar data atau hasil yang telah di dapatkan.

2. Pengelompokan berdasarkan Kategori, Tema dan Pola Jawaban

Pada tahap ini dibutuhkan pengertian yang mendalam terhadap data, perhatiaan yang penuh dan keterbukaan terhadap hal-hal yang muncul di luar apa yang ingin digali. Berdasarkan kerangka teori dan pedoman wawancara, peneliti menyusun sebuah kerangka awal analisis sebagai acuan dan pedoman dalam mekukan coding. Dengan pedoman ini, peneliti kemudian kembali membaca transkip wawancara dan melakukan coding, melakukan pemilihan data yang relevan dengan pokok pembicaraan. Data yang relevan diberi kode dan penjelasan singkat, kemudian dikelompokan atau dikategorikan berdasarkan kerangka analisis yang telah dibuat.

3. Menguji Asumsi atau Permasalahan yang ada terhadap Data

Setelah kategori pola data tergambar dengan jelas, peneliti menguji data tersebut terhadap asumsi yang dikembangkan dalam penelitian ini. Pada tahap ini kategori yang telah didapat melalui analisis ditinjau kemabali berdasarkan landasan teori yang telah dijabarkan dalam bab II, sehingga dapat dicocokan apakah ada kesamaan antara landasan teoritis dengan hasil yang dicapai. Walaupun penelitian ini tidak memiliki hipotesis tertentu, namun dari landasan teori dapat dibuat asumsi-asumsi mengenai hubungan antara konsep-konsep dan factor-faktor yang ada.

4. Mencari Alternatif Penjelasan bagi Data

Setelah kaitan antara kategori dan pola data dengan asumsi terwujud, peneliti masuk ke dalam tahap penejelasan. Dan berdasarkan kesimpulan yang telah didapat dari kaitanya tersebut, penulis merasa perlu mencari suatau alternative penjelasan lain tetnag kesimpulan yang telah didapat. Sebab dalam penelitian kualitatif memang selalu ada alternative penjelasan yang lain. Dari hasil analisis, ada kemungkinan terdapat hal-hal yang menyimpang dari asumsi atau tidak terfikir sebelumnya. Pada tahap ini akan dijelaskan dengan alternative lain melalui referensi atau teori-teori lain. Alternatif ini akan sangat berguna pada bagian pembahasan, kesimpulan dan saran. 
5. Menulis Hasil Penelitian

Penulisan data subjek yang telah berhasil dikumpulkan merupakan suatu hal yang membantu penulis unntuk memeriksa kembali apakah kesimpulan yang dibuat telah selesai. Dalam penelitian ini, penulisan yang dipakaiadalah presentase data yang didapat yaitu, penulisan data-data hasil penelitian berdasarkan wawancara mendalam dan observasi dengan subjek dan significant other. Proses dimulai dari data-data yang diperoleh dari subjek dan significant other, dibaca berulang kali sehinggga penulis mengerti benar permasalahanya, kemudian dianalisis, sehingga didapat gambaran mengenai penghayatan pengalaman dari subjek. Selanjutnya dilakukan interprestasi secara keseluruhan, dimana di dalamnya mencangkup keseluruhan kesimpulan dari hasil penelitian.

Analisis data pada penelitian ini menggunakan metode deskritif. Data yang diperoleh akan disusun secara sistematis dan dianalisis secara kualitatif untuk mencapai kejelasan masalah yang dibahas. Penelitian deskriptif ini tidak membutuhkan hipotesis. Tujuannya ialah memberikan gambaran subjek penelitian sebagaimana adanya. Dalam hal ini, penulis menganalisis dan menjelaskan hal-hal yang berkenaan dengan PT. Bank Perkreditan Rakyat Darul Imarah Jaya terutama keadaan laporan keuangannya.

Analisis kualitatif dilakukan dengan membandingkan antara teori dengan praktik. Pada analisis ini dilakukan perbandingan antara data yang didapatkan dari lapangan dengan data yang berasal dari studi kepustakaan sebagai landasn teoritas sehinnga dapat diambil kesimpulan mengenai kesesuaian sistem informasi akuntansi. Di samping itu, hasil wawancara akan dianalisis untuk mengetahui upaya apa saja yang dilakukan oleh PT. Bank Perkreditan Rakyat Darul Imarah Jaya agar penyusunan laporan keuangan sesuai dengan yang berbasis komputer serta hambatan apa saja yang dihadapi dalam penyusunan laporan keuangan itu sendiri

\section{HASIL PENELITIAN DAN PEMBAHASAN}

\section{Pengendalian Umum}

Pengendalian yang diterapkan pada sistem informasi sangat berguna untuk mencegah atau menjaga terjadinya hal-hal yang tidak diinginkan. Pengendalian umum ini bertujuan untuk memberikan keyakinan akan pengendalian intern di dalam lingkungan pengolahan data elektronik secara keseluruhan dapat tercapai. Selanjutnya akan dibahas setiap unsur pengendalian umum yang ada dalam pengolahan data akuntansi.

\section{Pengelolaan Organisasi}

Kebijakan manajemen atas pemiahan tugas dan tanggung jawab antara bagian pengiput data atau user dengan bagian pengelohan data adalah kerangka kerja yang penting dari pengendalian organisasi EDP. Pengendalian organisasi haruslah ditetapkan secara jelas dan tegas. Penyiapan dan input data dapat dilakukan oleh personil dari masing-masing bagian pengguna dengan batas password, sedangkan pengolahannya dibagian EDP. Pemisahan tugas yang dilakukan adalah:

1. Data entry operator, personil yang bertugas menyiapkan dan menginput data serta mengoperasikan komputer sesuai dengan petunjuk pelaksanaan operasi dan pesan-pesan dari konsol komputer. Tugas ini langsung dilakukan oleh masing-masing operator bagian pengguna (user).

2. System operator, bertugas mengoperasikan komputer, memonitor dan mengadakan kegiatan operasi komputer juga penggunaan printer.

\section{Pengendalian Dokumentasi}

Dokumen ini penting untuk keperluan mempelajari cara mengoperasikan sistem, sebagai bahan rujukan bagi karyawan baru untuk mempelajari mengoperasikan sistem informas, dasar pengembangan sistem lebih lanjut, dasar bila akan memodifikasikan atau memperbaiki sistem di kemudian hari dari dan materi acuan bagi pemeriksa sistem. Jenis-jenis dokumentasi yang dilakukan yaitu:

1. Dokumen operasi, yang berisi petunjuk-petunjuk untuk menjalankan suatu program, termasuk arsip masukan dan keluaran yang diprlukan serta unit-unit yang harus dipasang, prosedur penyetelan, daftar pesan program dan tindakan-tindakan yang ditetapkan.

2. Dokumentasi data, yang berisi definisi data item data di dalam database yang digunakan oleh sistem informasi. 
3. Dokumentasi program, menguraikan kegunaan suatu program dan menggambarkan logika dari program dalam bentuk bagan alir program.

4. Dokumentasi sistem, menguraikan kegunaan sistem pemrosesan dan deskripsi masukan, keluaran, serta deskripsi file-file yang digunakan.

5. Dokumentasi prosedur, berisi prosedur-prosedur yangharus dilakukan pada keadaan tertentu, seperti prosedur pengetasan program dan prosedur penggunaan file.

6. Dokumentasi hanya diberikan kepada yang berhak untuk memperolehnya.

\section{Pengendalian Perangkat Keras}

Untuk pengolahan data ini digunakan computer jenis mini yaitu HP 300. Mini komputer merupakan komputer multi tugas dan dapat mengendalikan berbagai peralatan masukan dan keluaran yang di pasang padanya. Perangkat keras komputer ini dilengkapi dengan beragam alat pengendalian terlekat. Perangkat keras yang digunakan adalah buatan IBM dan Hewlet Packard dimana pada perangkat keras tersebut telah dilengkapi tindakan pengamanan, seperti pengamanan data bila tiba-tiba daya listrik berkuran gsecara otomatis akan dilakukan bck-up. Dan ruangan komputer akan diberi penyejuk ruangan (AC) dan dilarang merokok agar peralatan yang ada tidak mudah rusak. Pengendalian perangkat keras lainnya dengan melakukan perawatan terhadap perangkat tersebut secara berlaku.

\section{Pengendalian Keamanan Fisik}

Pengendalian ini dilakukan untuk menjaga keamanan perangkat keras, perangkat lunak dan manusia dalam perusahaan. Pengemanan tidak sengaja menjaga agar fasilitas sistem EDP bebas dari akses tanpa izin, tetapi juga meliputi usaha-usaha untuk mencegah atau mengurangi kerugian yang mungkin timbul akibat adanya suatu kejadian mempengaruhi sistem EDP.

\section{Pengendalian Keamanan Data}

Pengendalian keamanan data dilakukan dengan cara membatasi akses, file-file diberi label yang terdiri dari nama, file number dan creation data. File hanya bias dilihat dan diproteksi oleh bagian EDP yang brtanggung jawab untuk melindungi seluruh data yang ada. Perlindungan terhadap data juga dilakukan dengan membuat back up. Secara rutin setiap akhir bulan EDP membuat back up ke Media Digital Data Storage. (DDS), yang memiliki kapasitas 40 Megabyte. Penggunaan DDS ini menguntungkan karena bentuknya sangat kecil (mungil) dan kemampuan menyimpan yang besar, bertolak belakang dengan Real Tape yang sangat besar sedangkan kemampuan menyimpan sangat kecil.

Pengendalian keamanan data juga dilakukan terhadap data entry operator, untuk meyakinkan bahwa transaksi yang dimaksud adalah transaksi yang valid, dan dilakukan oleh petugas yang diotorisasi untuk hal tersebut. Prosedur ini dilakukan untuk setiap kegiatan entry data. Sedangkan untuk memastikan bahwa suatu entry data hanya dilakukan oleh operator yang diotorisasi, maka setiap operator dilengkapi dengan password yang digunakan. Password Operating System pada saat "log on" dan password program aplikasi. Password Operating System pada saat log on meliputi:

1. User Password

2. Group paswaord

3. Account password, password pada saat menjalankan program menuju aplikasi tersebut.

4. Devision password

\section{Pengendalian Aplikasi}

Pengendalian aplikasi berhubungan dengan tugas-tugas khusus yang dilakukan oleh sistem pengelolaan data elektronik. Tujuan pengendalian aplikasi ini adalah untuk memberikan jaminan yang cukup bahwa pencatatan, pemrosesan dan pelaporan data sudah dilakukan dengan benar. Bedasarkan penelitian yang peneliti lakukan, prosedur yang tercakup dalam pengendalian ini adalah sebagai berikut:

\section{Pengendalian atas Masukan}

Pengendalian masukan dilakukan untuk memastikan bahwadata transaksi yang sah (valid) dicatat secara lengkap dan memberikan jaminan bahwa data yang salah dapat terdeteksi dan dikoreksi secara tepat waktu. Upaya yang dilakukan untuk memastikan bahwa transaksi yang sah di input secara lengkap adalah dengan melakukan pengecekan visual yaitu proses perbandingan data yang ada pada dokumen dengan input data yang muncul pada 
layar monitor komputer. Setelah operator yakin data yang dimasukkan adalah benar, barulah eksekusi terhadap data dapat dilakukan. Proses ini juga meliputi uji kelengkapan atas data input yang dientri.

Disamping itu proses pengendalian juga langsung dilakukan oleh program aplikasi, yaitu:

a. Registered entry, yaitu input data yang didaftarkan secara otomatis, lengkap dengan kode identitas operator dan keterangan lain menyangkut dengan entri data.

b. Logic check dan limit test, pelaksanaannya diatur oleh table kode transaksi yang bersifat permanen.

c. Self digit checking, yaitu pengendalian yang dilakukan berdasarkan penetapan table-tabel pengendalian yang berupa indikator yang dihasilkan dari pelaksanaan check digit verification.

Proses diteksi atas data input yang tidak memenuhi syarat dilaksanakan pada fase entri data, berupa penolakan langsung atas data yang tidak memenuhi syarat tersebut, sedangkan kesalahan-kesalahan tertentu yang bersifat kehilafan, dapat langsung disaring melalui proses pengendalian melekat seperti tersebut diatas. Prosedur yang dilakukan untuk menangani kesalahan dan ketidaklayakan pada saat entri data dapat langsung dilakukan koreksi oleh operator berdasarkan error massage yang diberikan oleh program aplikasi, dimana input yang diulang akan dapat kode yang tidak dapat dihapus.

\section{Pengendalian Keluaran}

Pengendalian atas keluaran (data output) dilakukan melalui prosedur pencocokan data output dengan input yang dilakukan oleh cheeker melalui perbandingan antara log control pemrosesan hasil up dating master file dengan total control input data yang dibuat berdasarkan dokumen sumber. Bila perbandingan (verifikasi) tersebut telah menunjukkan hasil yang benar, maka dilakukan uji test sampling atas beberapa dokumen sumber yang cukup berpengaruh menurut cheker. Bila pembandingan tidak menunjukkan kesesuaian, review dilakukan terhadap kesalahan dari input data, terutama dengan melihat log transaksi yang mempunyai tanda-tanda khusus.

Prosedur pengujian kelayak data output oleh checker tercakup dalam proses tersebut diatas, sedangkan review lanjutan atas data output yang berupa laporn dilakukan oleh seksi operasional melalui pembandingan input dan output (audit oround computer). Output dari proses yang menggunakan catatan online umumnya akan ditunjukkan dalam layar monitor kepemakaisehingga tidak diperlukan pengendalian terhadap bahan maupun distribusi laporan.

a. Journal printing, yaitu untuk memeriksa kelengkapan dan kebenaran input data transaksi (audit trail).

b. Balance proof checking, yaitu untuk memeriksa jumlah mutasi debet dan mutasi kredit dalam input data transaksi di file bak office.

c. Control transaksi dalam kondisi khusus, seperti transaksi koreksi/reverse, system locking bila terjadi overdraft dan juga pembayaran yang belum jatuh tempo, dispensasi dan lain-lain.

\section{Pembahasan Penerapan Sistem Informasi Akuntansi Berbasis Komputer}

Dalam sebuah perusahan perlu adanya sistem informasi akuntansi berbasis computer, dimana semakin pesatnya pemakai dalam menjalankan semua aktivitas yang dikerjakan dalam pencapaian keputusan. Oleh karena itu, computer merupakan sebagai salah satu unsur penting dalam pengolahan data penting menjadi perangkat yang sering digunakan dalam berbagai perusahaan jasa, dagang, maupun industri sehingga kemampuan komputer dalam pemrosesan data yang akan dijadikan informasi akan lebih cepat dan akurat.

Penerapan sistem informasi akuntansi berbasis computer pada PT. Bank Perkreditan Rakyat Darul Imarah Jaya sudah dilakukan dengan baik. Hal ini dapat dilihat dari penyaluran kredit yang diberikan dan dilakukan sesuai dengan sistem yang diberlakukan oleh PT. Bank Perkreditan Rakyat Darul Imarah Jaya dengan cara mengolah data yang dapat menghasilkan informasi yang berguna baik dalam menggunakan alat-alat, formulir-formulir dan catatan-catatan yang berisi bukti transaksi sehari-hari. Dalam perusahaan perlu adanya data yang akurat dimana bukti-bukti transaksi harus sesuai dengan jurnal dan buku besar sehingga laporan keuangan lebih mudah dipahami.

Dalam pelaksanaannya di perusahaan telah banyak membantu fungsi akuntansi sehingga memerlukan prosedur pelaksanaan pengendalian intern dengan computer antara lain sebagai berikut:

a. Pelaksanaan teknik berfungsi sebagai alat bantu bagi SIA yang digunakan oleh seorang akuntan dalam melakukan pemtoresan sistem untuk dianalisa, perancangan sistem dan implementasi dokumen sistem di lapangan.

b. Pelaksanaan operasional yang baik dengan computer akan menghasilkan data yang lebih cepat dan banyak sehingga akan meningkatkan kinerja operasional dalam perusahaan. 
c. Pelaksanaan ekonomi berguna dalam memperkecilkan biaya pengoperasian perusahaan yang tepat waktu guna membantu tugas dan fungsi akuntansi.

Pengoperasian program komputerisasi yang sangat sederhana dengan tidak mengabaikan kecepatan dan kecermatan hasil prosesnya, sehingga tenaga kerja yang ada lebih ditingkatkan kemampuannya untuk hal-hal yang bersifat analisa. Manfaat lain yang dapat diperoleh diantaranya:

a. Menyajikan laporan yang akurat dan tepat waktu

b. Sebagai bahan analisa rasio keuangan

c. Perencanaan anggaran dan cash flow.

\section{KESIMPULAN}

Berdasarkan hasil penelitian maka dapat diambil kesimpulan yang berhubungan dengan aplikasi sistem informasi akuntansi berbasis komputer pada PT. Bank Perkreditan Rakyat Darul Imarah Jaya antara lain sebagai berikut:

1. Dalam sebuah perusahan perlu adanya sistem informasi akuntansi berbasis komputer, dimana semakin pesatnya pemakai dalam menjalankan semua aktivitas yang dikerjakan dalam pencapaian keputusan. Oleh karena itu, komputer merupakan sebagai salah satu unsur penting dalam pengolahan data penting menjadi perangkat yang sering digunakan dalam berbagai perusahaan jasa, dagang, maupun industri sehingga kemampuan komputer dalam pemrosesan data yang akan dijadikan informasi akan lebih cepat dan akurat.

2. PT. Bank Perkreditan Rakyat Darul Imarah Jaya sudah menggunaan aplikasi sistem informasi akuntansi berbasis computer dengan demikian PT. Bank Perkreditan Rakyat Darul Imarah Jaya sudah menunjang proses akuntanbilitas, dan merupakan salah satu organisasi usaha yang bergerak pada bidang perbankan serta berperan dalam proses pemerataan pembangunan ekonomi dalam usaha meningkatkan taraf perekonomian pengusaha kecil khususnya yang berada di desa-desa. Oleh karena itu dapat dilihat dari pengolahan organisasi secara jelas dan tegas, dokumen yang baik, perangkat keras yang dilengkapi dengan tindakan pengamanan, keamanan fisik dan data yang terjaga serta komunikasi yang baik pada PT. Bank Perkreditan Rakyat Darul Imarah Jaya sehingga proses sistem informasi akuntansi berbasis komputer sudah memadai.

3. Fungsi komputer merupakan sebagai alat bantu pengolahan data elektronik yang telah dapat membantu dalam melakukan pengendalian intern dalam perusahaan terutama pada bagian akuntansi sehingga menghasilkan informasi berupa laporan keuangan.

4. Langkah-langkah penerapan komputerisasi yang telah dilakukan dalam pengolahan data akuntansi perusahaan merupakan salah satu kebijakan yang tepat untuk mendukung program aplikasi yang sesuai. Dimana informasi yang dihasilkan menjadi lebih cepat sehingga data antar bagian pengguna dapat saling terintegrasi.

5. Masalah dalam pengendalian masukan telah dilakukan untuk meminimalkan kesalahan saat posting, dan pengendalian atas keluaran yang dihasilkan sudah baik dengan dilakukan check and recheck atas output yang dihasilkan. Maka dilakukannya pengolahan data akuntansi komputer dan pengendaliannya, manajemen telah dapat mencapai tujuan agar informasi yang dihasilkan tepat waktu, tepat guna dan dapat dipercaya.

\section{Saran}

1. Dalam penerapan sistem informasi akuntansi berbasis komputer pihak pengolahan data hendak memeriksa dengan teliti setiap data akuntansi yang diterima oleh pihak PT. Bank Perkreditan Rakyat Darul Imarah Jaya baik dengan pengendalian akuntansi dan pengendalian administrasi.

2. Permasalahan bagi pihak manajemen pada PT. Bank Perkreditan Rakyat Darul Imarah Jaya diharapkan dapat terus meningkatkan kecakapan personilnya, khususnya personil yang terlibat dalam pengolahan data akuntansi, dan sebaiknya back up file yang disimpan di dalam DDS (Digital Data Storage). Hal ini untuk menghindari bila terjadi sesuatu yang tidak diinginkan seperti pencurian, penghancuran yang disengaja atau terbakar.

3. Sistem informasi akuntansi hendak mendukung keabsahan suatu transaksi supaya laporan keuangan tersebut dapat dipercaya karena ini merupakan suatu alat pengendali intern dan pengambilan keputusan untuk berbagai tujuan dalam mengolah data. 


\section{REFERENSI}

[1] Bahra, Al. 2003. Pengendalian Sistem Informasi Akuntansi. Edisi 5. ANDI. Yogyakarta.

[2] Baridwan, Zaki. 2004. Prosedur Pengendalian Sistem Informasi Akuntansi. Bumi Aksara: Jakarta.

[3] Bodnar, George H.J, Hopwood, William S. 2004. Sistem Informasi Akuntansi. Edisi 9. ANDI. Yogyakarta.

[4] Bodnar, George H.J.dan Hopwood, William S. 2000. Sistem Informasi Akuntansi. Edisi 5. ANDI. Yogyakarta.

[5] Brien. 2005. Sistem Informasi Akuntansi. UPP YPKN. Yogjakarta

[6] Cerullo, Wilkinson. 2007. Siklus Sistem Informasi Akuntansi. Salemba Empat. Jakarta

[7] Fakultas Ekonomi Universitas Syiah Kuala. 2010. Buku Panduan Penulisan Skripsi Program Studi Akuntansi. Banda Aceh : Fakultas Ekonomi Universitas Syiah Kuala.

[8] Fakultas Ekonomi Universitas Sebelas Maret. 2003. Buku Panduan Penyusunan Skripsi. FE UNS. Surakarta.

[9] Ikatan Akuntansi Indonesia. 2010. Persyaratan Standar Akuntansi Keuangan. Dewan Standar Akuntansi Ikatan Akuntan indonesia.

[10] James A. Hall. 2001. Akuntansi Islam. Jilid Satu. Bumi Aksara: Jakarta

[11] Kosasih. 2001. Sistem Informasi Akuntansi. Salemba Empat: Jakarta.

[12] Kabalmay, Marshall. 2002. Prosedur Penelitian, Suatu Pendekatan Praktik. Rineka Cipta. Jakarta

[13] Moleong. (2009). Prosedur Penelitian, Statisti Untuk Pendekatan Penelitian. Rineka Cipta. Jakarta

[14] Mulyadi. 2001. Sistem Akuntansi. Edisi 3. Salemba Empat. Jakarta

[15] Simanora, Henry. 2002. Prosedur Pengendalian Sistem Informasi Akuntansi. Bumi Aksara: Jakarta.

[16] Sekaran, U. 2006. Research Methods for Business Metode Penelitian Untuk Bisnis. Edisi 4. Salemba Empat. Jakarta

[17] Skousen, Stice, 2001. Akuntansi Keuangan Menengah. Edisi kesembilan, Jilid Satu, Terjemahan. Salemba Empat: Jakarta.

[18] Van Horne, James C. and John M. Wachowicz. 2005. Fundamentals of Financial: Management PrinsipPrinsip Manajemen Keuangan. Penerjemah: Dewi Fitriasari dan Deny Arnos Kwary. Salemba Empat: Jakarta.

[19] Wijayanto. 2001. Sistem Informasi Akuntansi. Bumi Aksara. Jakarta

[20] Yogiyanto. 2003. Pengendalian, Pengolahan Data Berbasis Komputer. Suatu Pengantar Edisi Ketiga. Erlangga. Jakarta. 